\title{
Playing cat and mouse: consumer empowerment and marketing interactions on the internet
}

\author{
Inma Rodríguez-Ardura* \\ Internet Interdisciplinary Institute \\ Open University of Catalonia (UOC) \\ Avda. Tibidabo 39-43, 08035 Barcelona, Spain \\ Fax: +34 934176495 \\ E-mail: irodriguez@uoc.edu \\ *Corresponding author
}

\section{Francisco J. Martínez-López}

University of Granada, Granada, Spain

E-mail: fjmlopez@ugr.es

\begin{abstract}
Since the internet was first used in the business world, researchers have been asking whether consumers have more power when they make their purchases using this channel and whether this makes electronic markets more efficient. No definitive answers for these questions have yet been found. The current work analyses the power game between consumers and companies online. The work considers the sources of consumer empowerment on the internet and the marketing initiatives that firms develop, which sometimes reduce consumers' power. The work also analyses the impact of these two factors on electronic markets in light of evidence from the literature examining their supposed greater efficiency. The article identifies various sources of power for the online consumer and stresses that different groups of consumers exercise this power at different levels of intensity.
\end{abstract}

Keywords: internet; consumer empowerment; electronic marketing; market efficiency; prices.

Reference to this paper should be made as follows: Rodríguez-Ardura, I. and Martínez-López, F.J. (xxxx) 'Playing cat and mouse: consumer empowerment and marketing interactions on the internet', Int. J. Business Environment, Vol. X, No. Y, pp.000-000.

Biographical notes: Inma Rodríguez-Ardura is an Associate Professor of Marketing in Economic and Business Studies and a Researcher at the Internet Interdisciplinary Institute of the Open University of Catalonia (Universitat Oberta de Catalunya or UOC), Spain. She obtained her PhD in Business Administration at the University of Barcelona. Her research interests include e-commerce, consumer behaviour on the internet and marketing e-learning. She is the author of several books and articles on these areas.

Francisco J. Martínez-López, MSc in Marketing, European PhD in Business Administration by the University of Granada, is an Associate Professor of Marketing at the University of Granada (Spain) and an Assistant Professor of Marketing at the UOC. Among his main areas of interest are consumer behaviour on the internet, e-marketing, marketing channels and Knowledge Discovery and Data Mining (KDD) methodologies for marketing. 


\section{Introduction}

In conventional environments and media, consumers often have a negative perception of the marketing initiatives they come into contact with (Gaski and Etzel, 2005; Sheth et al., 2006). This is often because they are repeatedly exposed to commercial programmes that do not meet their needs or preferences or burst intrusively into their daily lives. The fact is that consumers want to receive marketing proposals that are more precise and relevant, in other words, more closely matched to their individual needs and desires (Blattberg and Deighton, 1991; Peppers and Rogers, 1993). Consumers also often express an interest in having a greater capacity to intervene in the processes by which firms define and develop their value proposition (Pine, 1993), that is, the mix of benefits upon which the product or brand's positioning will be established. They also want to receive some compensation for the time and effort they dedicate to firms' marketing initiatives (Smith, 2006). Such compensation includes promotions and lower prices (Jensen et al., 2003), doses of entertainment, accurate and objective information, tools that help them in their purchase decisions or greater convenience (Chiang and Dholakia, 2003). But until the appearance of the internet and its associated interactive technologies in business, marketing programmes, far from adapting more closely to consumer demands for more power and a closer fit to their interests, seemed to be moving further away. Indeed, the strong and growing competitive pressure which firms are subjected to seemed to push them into adopting more frequent and aggressive conventional commercial practices, which did not satisfy consumer wants. Thus, the consumers, who have traditionally had few mechanisms to defend themselves against undesired marketing actions, opted to pay increasingly less attention and show even less interest in this type of commercial programme, which led to a considerable reduction in their efficacy (Smith, 2006).

This outlook was seemingly destined for a radical change when in the second half of the 1990s, authors first began to reflect on the potential impact of Information Technology (IT) and internet use on firms and consumers. Pioneering work, such as that in Alba et al. (1997), foresaw substantial changes as a result, on one hand, of firms matching their potential customers' requirements of greater satisfaction and empowerment more closely and, on the other hand, of the consumers behaving more rationally and efficiently in their purchase and consumption activities. Some authors even suggested that IT would provoke a paradigm shift in the relationship between firms and consumers (e.g., Hoffman and Novak, 1996; Hoffman, 2000). This idea, however, did not receive unanimous support. In fact, other authors considered that the way firms tended to behave in their interactions with consumers would continue to be valid on the internet (Harris and Cohen, 2003). Others defended the validity of the majority of marketing principles and orientations in the new electronic markets, even if firms would have to adapt their strategies and tactics to this medium (Chaffey et al., 2000).

Since then, electronic markets have offered some important lessons in marketing. Some firms, such as Amazon, eBay, Google, Peapod, Priceline and Yahoo!, know their consumers better through IT and use interactive mechanisms to adapt their marketing initiatives to their consumers' demand for the information they receive to be more precise and relevant and for intervention in the formulation of value proposition or more reciprocity (Smith, 2006). Amazon builds a constructive and fruitful dialogue with each of its customers. Peapod and Priceline offer high levels of convenience and economy, respectively, in the purchase process. The question is whether these cases, which are still 
relatively isolated, are the first signs of a significant transformation in the way firms manage their relationships with their customers and win their involvement or whether, in contrast, they will have a limited impact on the competitive game. Indeed, some of these initiatives are merely complementary or incidental to the conventional business strategies, either because firms use the internet mainly for their marketing communications and do not fully exploit its interactive potential in other areas because firms have a relatively small share of the product/market, or because the positive impact of these initiatives on customer loyalty and business performance has not yet been sufficiently demonstrated (Lee-Kelley et al., 2003; Vilaseca et al., 2007).

On the other hand, the role that consumers play in the electronic markets seems to be unclear, too. Initially, the impression was that consumers would use the internet to get a great deal of (more appropriate) information about an offer and that they would use this information to adopt more efficient purchase decisions based on more objective criteria. This would enhance their power in their relationships with firms. These changes, had they occurred, would have led to an even more fierce competition between the firms, which would have eventually resulted in a competitive situation very close to perfect competition with a consequent significant reduction in prices (Bakos, 1997; Brynjolfsson and Smith, 2000). But the evidence suggests that these practices have a limited impact (e.g., Degeratu et al., 2000; Lindsey-Mullikin and Grewal, 2006).

The lack of definitive evidence on these questions justifies the objective of the current work, which is to investigate the roles that consumers and firms play in their interactions in electronic markets. Thus, if at first it seemed that consumers should have greater power when they act on the internet, which should make the electronic markets more efficient, the literature has not confirmed that consumers deploy a bigger empowerment. This may be because consumers are continuing to show behaviour patterns that are similar to the ones they have in conventional environments or because firms, making use of various mechanisms, are preventing consumers from exercising a direct and effective influence on their marketing initiatives. After identifying and analysing the online consumers' sources of empowerment and several of the firms' online marketing strategies that can limit consumer power, this article looks at some evidence from the literature. On one hand, the literature shows some evidence about the benefits that consumers seek from the internet and about their online purchase behaviour. This sheds light on the way they actually exercise their power individually. On the other hand, it provides some evidence at the aggregate level about the interactions between consumers and firms in electronic markets. From all of this, the work deduces some conclusions and managerial implications about how the new digital medium affects consumer empowerment and the consumers' relationship with marketing.

\section{The sources of empowerment for online consumers}

Since firms started to use the internet in their marketing activities, various authors in the field of consumer behaviour, following Alba et al. (1997), have stressed the internet's potential to enhance consumer satisfaction and empowerment (e.g., Harrison et al., 2006; Pires et al., 2006; Pitt et al., 2002; Rezabakhsh et al., 2006). Authors have often justified this enhanced consumer power by pointing to the greater availability of information about the products on offer (Bakos, 1997). But another explanation might be the consumers' 
increased capacity to directly intervene in the shaping of a value proposition adapted to their specific preferences (Pires et al., 2006), as well as their greater capacity to 'sanction' firms (Rezabakhsh et al., 2006).

In conventional environments, consumers have access to only a limited amount of information to help them select their consideration set and evaluate each of the possible alternatives that this set contains. Consumers also have little opportunity to directly intervene in defining and developing the value proposition. Ultimately, they end up exercising their influence through the perceptions that form when they interact with the firm and its offer with their decisions to purchase or reject the products on offer (Wright et al., 2006) and through the word-of-mouth that they spread among the people in their close circle. Word-of-mouth has a considerable influence on other consumers' attitudes and purchase behaviours, but it has a limited reach (Feick and Price, 1987). Thus, consumers can only exercise an important influence on firms and their marketing initiatives when they act in unison and in large numbers (Grønmo and Ölander, 1991) or when they justifiably request the intervention of the public authorities.

However, the possibilities that the internet offers for many-to-many interactive communication (Hoffman and Novak, 1996) and the low costs per contact mean that firms can considerably increase the information that they make available to consumers in electronic markets. On one hand, firms can exploit the advantages of the internet in communications and extensively use the internet to make their value proposition known and provide abundant information about it. On the other hand, the consumers themselves, both individually and when organised in groups, can use the internet to disseminate their opinions and experiences about the products to the community (Ryu and Feick, 2007). Apart from the considerable increase in information that is available to the consumer, consumers also have tools (like shopbots) at their disposal. These instruments considerably reduce the costs of searching for, comparing and evaluating commercial offers, making it easier for consumers to find the most appropriate products or services. This greater availability of information, together with the lower cost of obtaining it, should reduce the information asymmetries that have traditionally existed between firms and their customers, as well as the opportunistic behaviours of the former (Alba et al., 1997; Bakos, 1997; Brynjolfsson and Smith, 2000).

The consumers' capacity to influence the design of the value proposition can also increase on the internet (Rezabakhsh et al., 2006). This is not only because they can use different formats of commercial intermediation to set the price they will pay for the product (grouping their purchases and setting a price for them, negotiating the price when participating in auction systems, etc.), but also because they can use mechanisms that allow them to design the characteristics of the product and participate in the production of a product/service that is customised to their requirements (Kamali and Loker, 2002).

Consumers can also exercise greater power to sanction firms via online communication (Rezabakhsh et al., 2006). The most active consumers, acting as opinion leaders, can become very effective at disseminating - quickly and very loudly - information, personal assessments and recommendations about firms, their brands and their products (Carl, 2006).

This reasoning led an important research line, which emerged at the end of the 1990s (e.g., Bakos, 1997; Brynjolfsson and Smith, 2000) to assume the hypothesis that consumers have greater power on the internet. On the basis of the literature on the economics of information (Stigler, 1961), these authors predicted that if consumers started to use the internet en masse in their purchase decision processes, particularly in 
the stages of searching for and comparing alternatives, the competition between firms would become more intense. Consequently, prices would fall to levels that are close to those of the perfect competition situation. This would make the internet a frictionless and highly efficient marketplace (Bakos, 1997; Brynjolfsson and Smith, 2000).

\section{The marketing strategies that restrict empowerment}

Shortly after the frictionless commerce hypothesis was formulated, the first doubts were expressed (e.g., Lal and Sarvary, 1999; Lynch and Ariely, 2000). A scenario of perfect competition is a very bleak prospect for firms, so they began to use online strategies that limit the effectiveness of the consumers' search for information, reduce their price sensitivity (e.g., Acquisti and Varian, 2005; Kung et al., 2002; Zettelmeyer, 2000) and strengthen their loyalty. This would incidentally limit the consumers' freedom of action.

Although firms have incentives to increase consumers' empowerment and provide them with greater levels of information and interaction (a greater adaptation to consumers' demands improves their satisfaction and, consequently, the firms' performance), firms do not always design their initiatives with this objective. According to Zettelmeyer (2000), when the internet has reached a high penetration in the target market, firms have no incentives to provide more information online about the characteristics of the value proposition than what they normally provide in conventional channels. Following a similar strategy to the one they use in conventional environments means that firms avoid conflict with the competitors that they have been differentiating themselves from on the basis, among other aspects, of the wealth of provided information.

The literature describes various mechanisms to reduce the efficacy and efficiency of information search activities on the internet, thereby reducing consumer empowerment. These mechanisms include dynamic price adjustments, discrimination strategies and the 'hit and run' strategy (Baye et al., 2004b), the differentiation of the offer and tactics to confuse searches. Dynamic adjustments involve modifying the product and particularly, its price, very rapidly, frequently and in a way that the consumer cannot make a prediction (Oh and Lucas, 2006). These practices, which, according to Oh and Lucas (2006), are particularly common when firms increase prices, exploit the consumers' 'rational inattention' (Sims, 2003) to small variations in the price. Firms are very quick to transfer small price rises to the consumer, but wait rather longer to transfer price cuts until they are sure that the price cut is sufficient for the consumers to notice (Oh and Lucas, 2006).

Other online strategies exploit the existence of loyal, risk-averse or uninformed consumers, who respectively have a high brand preference, perceive a high risk in purchasing online or are not aware of or have not learned to use the search or communication mechanisms that enhance their empowerment. Firms usually offer prices that are relatively higher and more closely adapted to these segments of consumers (Deck and Wilson, 2006; Hernandez, 2002), since they are willing to pay a 'premium' (Grover et al., 2006) to reduce the risks of the transaction or save themselves from the effort of searching, which is too onerous for them. In contrast, to attract the informed consumers who are able to spot an offer more easily (because they use shopbots, for example), firms 
use a hit and run strategy (Baye et al., 2004b), where the price cuts are occasional, unpredictable and short-lived. This strategy has the additional advantage that because of its short duration, it rarely provokes a price war with competitors.

Firms also use differentiation strategies (differentiating on the basis of the virtual purchase environment, the image and reputation of the brand, product quality, etc.), which encourage customers to compare products on the basis of nonprice attributes, thereby reducing their price sensitivity (Lynch and Ariely, 2000; Sotgiu and Ancarani, 2005).

In order to avoid comparisons, some firms with high prices systematically reduce the information they publish in their websites about their products (Pan et al., 2004) and keep their products away from shopbots or other informediaries or, at least, limit the information provided to special promotions (Smith, 2002). The latter means that the brand or company earns an image of 'value for money' that is not necessarily deserved, given the prices of the remaining products in its product range.

Apart from this set of practices, which reduce the effectiveness of internet searches, firms employ other initiatives that also contribute to the restriction of consumer empowerment, either because they condition or influence informal communications among consumers or because they do not allow them to take part in the design of the value proposition. Chief among these are the marketing communication programmes that prevent or limit the spread of rumours that are harmful to the firm and encourage the spread of favourable communications (buzz marketing) and viral marketing programmes, which exploit online mechanisms for word-of-mouth communication between consumers (Carl, 2006).

Likewise, consumers have few real opportunities to intervene in the value chain, actively participate in the design and manufacture of the product or customise the product to meet their needs (Rezabakhsh et al., 2006), even when the firm has implemented Customer Relationship Management (CRM) strategies and technologies. Boulding et al. (2005), for example, observed that many CRM initiatives are accompanied by a traditional segmentation and lack any customisation mechanisms.

\section{Consumer motivations and behaviours online: some evidence}

At present, the literature offers some evidence about the benefits that consumers seek from the internet and about their online purchase behaviour. This sheds some light on the way they actually exercise their power as consumers.

On one hand, the internet seems to be turning into an important source of information in consumers' purchase decision processes. Thus, regardless of the channel in which they finally make their purchases, consumers use the internet to search for and compare products; Media-Screen (Marketing Management, 2007), for example, calculates that half of all the purchases that US consumers made in 2006 were influenced by online sources. The consulted information does not come only from the firms: increasingly, consumers obtain information from virtual spaces run by other users (Marketing Management, 2007). In parallel, consumers are increasingly using shopbots to make their searches and comparisons, so that a significant segment of internet users use such tools, at least, sometimes (Deck and Wilson, 2006; Sen et al., 2006). Consumers can use these tools to make advanced searches about the functional or objective attributes of firms' offers and 
identify higher-quality, cheaper or otherwise more suitable alternatives. Moreover, and as a result of this greater familiarity with online purchase systems, these consumers can more easily defend themselves against the firms that use dynamic marketing strategies (which exploit information about their preferences and previous purchase behaviours). They can eliminate cookies, use anonymous forms of payment or publicise their unhappiness with the marketing initiatives that they consider intrusive, discriminatory or otherwise unsatisfactory (Acquisti and Varian, 2005).

A very different situation from these internet users is that of the many other consumers who are not familiar with or do not use this type of tool, either because they are less of an expert in using the internet or because it is too costly for them to learn to use the tool as a source of information. This segment typically uses heuristics and shortcuts in their decision processes (Martínez-López et al., 2005b; Rezabakhsh et al., 2006), although they are aware that they may have to pay higher prices as a consequence (Deck and Wilson, 2006; Grover et al., 2006).

Even the informed consumers make limited use of the advanced search tools. Research suggests, for example, that the more the experienced consumers are in the medium, the less they use such tools (Rezabakhsh et al., 2006) and even when they do use such tools, they often end up choosing firms with respected brands or firms that they have previously visited (Smith, 2002). Thus, they resort to the brand as an indicator of those attributes (e.g., shipping reliability) about which the shopbot does not, in their opinion, provide sufficient information (Smith and Brynjolfsson, 2001).

The search costs on the internet, although lower than in physical environments (Häubl and Trifts, 2000), are not zero (Baylis and Perloff, 2002). If they were, consumers would dedicate more time and effort in searching for information (Grover et al., 2006). Although consumers can get information for the transaction, this is often not entirely satisfactory. The information may be excessive, which makes cognitive processing difficult (Suri et al., 2003) or confusing, incoherent or incomprehensible (Grover et al., 2006). For example, systems that offer assessments and rankings of products also offer subjective evaluations from consumers who frequently contradict each other.

A particularly distinctive characteristic of online purchase processes is their convenience. Research has identified this as one of the most important purchase motivations for consumers, often more important than obtaining other benefits (Chiang and Dholakia, 2003). In fact, offering greater levels of convenience and other aspects that add value for the customer justifies a higher price (Sotgiu and Ancarani, 2005). Moreover, various studies found that consumers are no more sensitive to prices online than they are in conventional environments (e.g., Degeratu et al., 2000; Jensen et al., 2003; Sotgiu and Ancarani, 2005).

Other researchers stress the importance of functional or utilitarian motivations in consumers' online purchase processes (e.g., Dahlén and Lange, 2002; Martínez-López et al., 2006a; Ratchford et al., 2001; Rezabakhsh et al., 2006). For example, Dahlén and Lange (2002), studying a sample of the customers of an online Swedish store, found that consumers tend to make fewer unplanned purchases than in conventional stores and minimise the number of visits to the site, which means that they make more large-volume purchases for stockpiling purposes. The authors attributed this behaviour to the fact that the consumers find these virtual stores unattractive and unstimulating. 


\section{Evidence of empowerment in the market}

Another way of understanding consumer power on the internet is to analyse, in an aggregate form, the interaction of the group of consumers in their relationship with the firms. In fact, researchers have commonly related the supposed greater efficiency of electronic markets with the empowerment of the consumers (e.g., Alba et al., 1997; Harrison et al., 2006). The explanation for this would be that online consumers, who have a greater capacity for evaluating their different purchase options, intervening in the first stages of the value chain and communicating with firms and other consumers, would be more able to adopt efficient purchase decisions (i.e., acquiring the desired product more cheaply). This way of behaving would provoke an intense competition among the firms, fundamentally on the basis of price (Bakos, 1997; Brynjolfsson and Smith, 2000).

Nevertheless, the various works that have investigated whether prices converge downwards on the internet provide contradictory findings. Comparing the price levels between online and conventional stores by product/market, Bailey (1998), for example, found that prices are higher online for books, Compact Discs (CDs) and software. Clay et al. (2002) and Stylianou et al. (2005) obtained similar results for books and pharmaceutical products, respectively, although both cases considered the total price paid by the consumer (including taxes and shipping). Similarly, Xing et al. (2004) also obtained higher prices for consumer electronics online. In contrast, other - more numerous - studies found lower prices on the internet. This is the case, for example, of Brynjolfsson and Smith (2000) for books and CDs, Clemons et al. (2002) for air travel, Brown and Goolsbee (2002) for life insurance, Lee and Gosain (2002) for CDs, Strader and Shaw (1999) for sports trading cards and Zettelmeyer et al. (2006) for cars.

Researchers seem to have reached more consensus around the idea that electronic markets have a high and persistent price dispersion (Baylis and Perloff, 2002; Baye et al., 2004a; Bailey, 1998; Clay et al., 2002; Clemons et al., 2002; Lee and Gosain, 2002). Despite this, subsequent longitudinal analyses carried out for some specific product/markets, such as air travel (Chen, 2006), or using the shopbot BizRate (Ratchford et al., 2003) detected a trend towards some convergence in prices.

Authors have suggested various causes for price dispersion on the internet. Those related to market characteristics include the market structure (i.e., the number of competitors) (Baye et al., 2004b; Clay et al., 2001; Nelson et al., 2007) and the consumers' heterogeneity with respect to their search costs (Acquisti and Varian, 2005; Baylis and Perloff, 2002; Deck and Wilson, 2006). Other factors, in contrast, have to do with the firm and, more specifically, with its application of price discrimination strategies (Clemons et al., 2002), its use of occasional promotions that are unpredictable to the consumer (Baye et al., 2004b), the delivery of different levels of convenience, breadths of assortment or information (Walter et al., 2006), brand awareness and reputation (Pan et al., 2002; Smith and Brynjolfsson, 2001; Xing et al., 2006) and the presence of the brand in conventional environments (i.e., multichannel strategy) (Ancarani and Shankar, 2004; Pan et al., 2002; Tang and Xing, 2001). Finally, some researchers found a relation between the unit price of the product and price dispersion: consumers evaluate price savings in relative (not absolute) terms, so they search less in purchase decision processes for high-priced products. This leads to a greater price dispersion in these cases (Lindsey-Mullikin and Grewal, 2006; Nelson et al., 2007). 


\section{Conclusions and managerial implications}

In order to analyse the impact of the internet on the enhancement of consumer empowerment, the current work has considered the way the internet influences the consumers' capacity to undertake their purchase/consumption decision processes, as well as the marketing initiatives that firms employ in the process of interacting with their consumers.

The internet offers consumers new opportunities to enhance their empowerment. The main source of empowerment in the internet is usually considered to lie in the ease with which consumers can obtain large amounts of information that is relevant to them and, moreover, do so quickly and cheaply. This considerably reduces the information asymmetries that are commonly seen between consumers and firms. But this idea needs to be qualified. On one hand, the cost of obtaining information on the internet, although less than that in conventional environments, is not zero: consumers suffer from information overload or ambiguous or confusing information and they need to invest time and effort in learning how to properly use, for example, online search tools. On the other hand, the ability to intervene in the design of the value proposition and the ability to interactively and widely communicate with other consumers are also sources of empowerment.

Firms, for their part, have strong incentives to try to improve consumer satisfaction and empowerment and, rather than treat their consumers as their opponents, to develop exchanges and interactions, within which both sides collaborate in the creation and reproduction of the market (Denegri-Knott et al., 2006). A constant focus on discovering the consumers' expectations, encouraging their collaboration and developing and delivering the value that meets these expectations, tends to result in a fruitful relationship for both parties.

But the panorama that is sometimes foreseen as the consequence of consumers' increasing power on the internet is rather bleak for firms. Specifically, Alba et al. (1997) and other authors (Bakos, 1997; Brynjolfsson and Smith, 2000) forecasted an intensification of the competition between firms that is based on price as a result of falling consumer search costs and the ease with which consumers can detect the value proposition that most closely meets their requirements in each particular case. All this should supposedly make the internet a more efficient market, approaching the situation of perfect competition. This scenario, which is very unattractive for the firms, would explain their efforts to design marketing strategies that either do not offer more empowerment to the consumers or even limit such power (i.e., hit and run strategies or tactics for confusing the information search tools).

In any case, the contradictory results obtained in the empirical analyses carried out to date into both the price level and price dispersion mean that the hypothesis that the internet is a more efficient market cannot be confirmed. Alternative explanations might be suggested, such as that the consumers, with their lower search costs and higher levels of empowerment, are not the only beneficiaries of the internet. Firms also find it easier to obtain information from their consumers, interact with them and develop suitably adapted marketing programmes.

Moreover, the obtained evidence about consumers' motivations and behaviours on the internet reveals diverse behaviour patterns among them. On one hand, an important segment of consumers presents high search costs and little inclination to increase 
their levels of empowerment. When these consumers perceive these asymmetries of information and power, they conceivably try to reduce the risk inherent in the commercial relationship online by establishing links of confidence via the brand and brand loyalty, although this means that they will have to pay a premium. Another group of consumers are more informed and active. These consumers use the internet to enhance their empowerment. They are ready to defend themselves against firms' opportunistic initiatives and participate in the creation of a value proposition that satisfies their requirements and they know how to disseminate their opinions and recommendations among many other consumers.

Consequently, firms must take into account a new element when they design their marketing initiatives: whether or not the consumer wishes to exercise greater empowerment. Firms should present the consumers who are less interested in exercising empowerment with opportunities to develop the chain of 'value delivery-loyalty', saving their efforts, strengthening the reputation of the brand, developing more pleasant shopping environments and so on. For the more active and informed consumers who wish to exercise their empowerment on the internet, firms should develop marketing initiatives that will allow them to feel that they are in control of their purchase and consumption experiences. In either case, if firms intelligently use information systems to get to know their customers better, identify whether they are willing to participate actively in the market, renew their customer relationship orientation and strive to satisfy their customers, then the firms will find new opportunities online to improve their value propositions and obtain competitive advantages.

\section{Acknowledgements}

The authors would like to thank Antoni Meseguer-Artola, whose valuable comments and suggestions helped in the preparation of this work.

\section{References}

Acquisti, A. and Varian, H.R. (2005) 'Conditioning prices on purchase history', Marketing Science, Vol. 24, No. 3, pp.367-381.

Alba, J., Lynch, J., Weitz, B., Janiszewski, C., Lutz, R., Sawyer, A. and Wood, S. (1997) 'Interactive home shopping: consumer, retailer, and manufacturer incentives to participate in electronic marketplaces', Journal of Marketing, Vol. 61, No. 3, pp.38-53.

Ancarani, F. and Shankar, V. (2004) 'Price levels and price dispersion within and across multiple e-tailer types: further evidence and extension', Journal of the Academy of Marketing Science, Vol. 32, No. 2, pp.176-187.

Bailey, J.P. (1998) 'Electronic commerce: prices and consumer issues for three products: books, compact discs, and software', DSTI/ICCP/IE(98)4, Paris: OECD.

Bakos, J.Y. (1997) 'Reducing buyer search costs: implications for electronic marketplaces', Management Science, Vol. 43, No. 12, pp.1676-1692.

Baye, M.R., Morgan, J. and Scholten, P. (2004a) 'Price dispersion in the small and in the large: evidence from an internet price comparison site', The Journal of Industrial Economics, Vol. 52, No. 4, pp.463-496. 
Baye, M.R., Morgan, J. and Scholten, P. (2004b) 'Temporal price dispersion: evidence from an online consumer electronics market', Journal of Interactive Marketing, Vol. 18, No. 4, pp.101-115.

Baylis, K. and Perloff, J. (2002) 'Price dispersion on the internet: good firms and bad firms', Review of Industrial Organization, Vol. 21, No. 3, pp.305-324.

Blattberg, C.R. and Deighton, J. (1991) 'Interactive marketing: exploring the age of addressability', Sloan Management Review, Vol. 33, No. 1, pp.5-14.

Boulding, B., Staelin, R., Ehret, M. and Johnston, W.J. (2005) 'A customer relationship management roadmap: what is known, potential pitfalls, and where to go', Journal of Marketing, Vol. 69, No. 4, pp.155-166.

Brown, J.R. and Goolsbee, A. (2002) 'Does the internet make markets more competitive? Evidence from the life insurance industry', Journal of Political Economy, Vol. 110, No. 3, pp.481-507.

Brynjolfsson, E. and Smith, M.D. (2000) 'Frictionless commerce? A comparison of internet and conventional retailers', Management Science, Vol. 46, No. 4, pp.563-585.

Carl, W.J. (2006) 'What's all the buzz about?', Management Communication Quarterly, Vol. 19, No. 4, pp.601-634.

Chaffey, D., Mayer, R., Johnston, K. and Ellis-Chadwick, F. (2000) Internet Marketing: Strategy, Implementation and Practice, Harlow, UK: Prentice Hall.

Chen, J. (2006) 'Differences in average prices on the internet: evidence from the online market for air travel', Economic Inquiry, Vol. 44, No. 4, pp.656-670.

Chiang, K-P. and Dholakia, R.R. (2003) 'Factors driving consumer intention to shop online: an empirical investigation', Journal of Consumer Psychology, Vol. 13, Nos. 1-2, pp.177-183.

Clay, K., Krishnan, R. and Wolff, E. (2001) 'Prices and price dispersion on the web: evidence from the online book industry', Journal of Industrial Economics, Vol. 49, No. 4, pp.521-539.

Clay, K., Krishnan, R., Wolff, E. and Fernandes, D. (2002) 'Retail strategies on the web: price and non-price competition in the online book industry', Journal of Industrial Economics, Vol. 50, No. 3, pp.351-367.

Clemons, E.K., Hann, I-H. and Hitt, L.M. (2002) 'Price dispersion and differentiation in online travel: an empirical investigation', Management Science, Vol. 48, No. 4, pp.534-549.

Dahlén, M. and Lange, F. (2002) 'Real consumers in the virtual store', Scandinavian Journal of Management, Vol. 18, No. 3, pp.341-363.

Deck, C.A. and Wilson, B.J. (2006) 'Tracking customer search to price discriminate', Economic Inquiry, Vol. 44, No. 2, pp.280-295.

Degeratu, A.M., Rangaswamy, A. and Wu, J. (2000) 'Consumer choice behavior in online and traditional supermarkets: the effects of brand name, price, and other search attributes', International Journal of Research in Marketing, Vol. 17, No. 1, pp.55-78.

Denegri-Knott, J., Zwick, D. and Schroeder, J.E. (2006) 'Mapping consumer power: an integrative framework for marketing and consumer research', European Journal of Marketing, Vol. 40, Nos. 9-10, pp.950-971.

Feick, L.F. and Price, L.L. (1987) 'The market maven: a diffuser of marketplace information', Journal of Marketing, Vol. 51, No. 1, pp.83-97.

Gaski, J.F. and Etzel, M.J. (2005) 'National aggregate consumer sentiment toward marketing: a thirty-year retrospective and analysis', Journal of Consumer Research, Vol. 31, No. 4, pp.859-867.

Grønmo, S. and Ölander, F. (1991) 'Consumer power: enabling and limiting factors', Journal of Consumer Policy, Vol. 14, No. 2, pp.141-169.

Grover, V., Lim, J. and Ayyagari, R. (2006) 'The dark side of information and market efficiency in e-markets', Decision Sciences, Vol. 37, No. 3, pp.297-324.

Harris, L. and Cohen, G. (2003) 'Marketing in the internet age: what can we learn from the past?', Management Decision, Vol. 41, No. 9, pp.944-956. 
Harrison, T., Waite, K. and Hunter, G.L. (2006) 'The internet, information and empowerment', European Journal of Marketing, Vol. 40, Nos. 9-10, pp.972-993.

Häubl, G. and Trifts, V. (2000) 'Consumer decision making in online shopping environments: the effects of interactive decision aids', Marketing Science, Vol. 19, No. 1, pp.4-22.

Hernandez, J.M.C. (2002) 'Brand trust and online consumer behavior', Advances in Consumer Research, Vol. 29, No. 1, pp.255-256.

Hoffman, D.L. (2000) 'The revolution will not be televised: introduction to the special issue on marketing science and the internet', Marketing Science, Vol. 19, No. 1, pp.1-3.

Hoffman, D.L. and Novak, T.P. (1996) 'Marketing in hypermedia computer-mediated environments: conceptual foundations', Journal of Marketing, Vol. 60, No. 3, pp.50-68.

Jensen, T., Kees, J., Burton, S. and Turnipseed, F.L. (2003) 'Advertised reference prices in an internet environment: effects on consumer price perceptions and channel search intentions', Journal of Interactive Marketing, Vol. 17, No. 2, pp.20-33.

Kamali, N. and Loker, S. (2002) 'Mass customization: on-line consumer involvement in product design', Journal of Computer-Mediated Communication, Vol. 7, No. 4, http://jcmc.indiana .edu/vol7/issue4/loker.html.

Kung, M., Monroe, K.B. and Cox, J.L. (2002) 'Pricing on the internet', Journal of Product \& Brand Management, Vol. 11, No. 5, pp.274-287.

Lal, R. and Sarvary, M. (1999) 'When and how is the internet likely to decrease price competition?', Marketing Science, Vol. 18, No. 4, pp.485-503.

Lee, Z. and Gosain, S. (2002) 'A longitudinal price comparison for music CDs in electronic and brick-and-mortar markets: pricing strategies in emergent electronic commerce', Journal of Business Strategies, Vol. 19, No. 1, pp.55-71.

Lee-Kelley, L., Gilbert, D. and Mannicom, R. (2003) 'How e-CRM can enhance customer loyalty', Marketing Intelligence \& Planning, Vol. 21, No. 4, pp.239-248.

Lindsey-Mullikin, J. and Grewal, D. (2006) 'Imperfect information: the persistence of price dispersion on the web', Journal of the Academy of Marketing Science, Vol. 34, No. 2, pp.236-243.

Lynch, J.G. and Ariely, D. (2000) 'Wine online: search costs affect competition on price, quality, and distribution', Marketing Science, Vol. 19, No. 1, pp.83-103.

Marketing Management (2007) 'Shop and compare', Marketing Management, Vol. 16, No. 2, p.7.

Martínez-López, F., Luna, P. and Martínez, F.J. (2006a) 'Motivations for consumption behaviours on the web: a conceptual model based on a holistic approach', International Journal of Electronic Marketing and Retailing, Vol. 1, No. 1, pp.3-20.

Martínez-López, F., Luna, P. and Martínez, F.J. (2006b) 'Online shopping, the standard leaning hierarchy, and consumers' internet expertise: an American-Spanish comparison', Internet Research, Vol. 15, No. 3, pp.312-334.

Nelson, R.A., Cohen, R. and Rasmussen, F.R. (2007) 'An analysis of pricing strategy and price dispersion on the internet', Eastern Economic Journal, Vol. 33, No. 1, pp.95-110.

Oh, W. and Lucas, H.C. (2006) 'Information technology and pricing decisions: price adjustments in online computer markets', MIS Quarterly, Vol. 30, No. 3, pp.755-775.

Pan, X., Ratchford, B.T. and Shankar, V. (2002) 'Can price dispersion in online markets be explained by differences in e-tailer service quality?', Journal of the Academy of Marketing Science, Vol. 30, No. 4, pp.433-445.

Pan, X., Ratchford, B.T. and Shankar, V. (2004) 'Price dispersion on the internet: a review and directions for future research', Journal of Interactive Marketing, Vol. 18, No. 4, pp.116-135.

Peppers, D. and Rogers, M. (1993) The One-to-One Future: Building Relationships One Customer at a Time, New York: Currency/Doubleday.

Pine, J.B. (1993) Mass Customization. The New Frontier of Business Competition, Boston, MA: Harvard University Press. 
Pires, G.D., Stanton, J. and Rita, P. (2006) 'The internet, consumer empowerment and marketing strategies', European Journal of Marketing, Vol. 40, Nos. 9-10, pp.936-949.

Pitt, L.F., Berthon, P.R., Watson, T.R. and Zinkhan, G. (2002) 'The internet and the birth of real consumer power', Business Horizons, Vol. 45, No. 6, pp.7-14.

Ratchford, B.T., Pan, X. and Venkatesh, S. (2003) 'On the efficiency of internet markets for consumer goods', Journal of Public Policy \& Marketing, Vol. 22, No. 1, pp.4-16.

Ratchford, B.T., Talukdar, D. and Lee, M-S. (2001) 'A model of consumer choice of the internet as an information source', International Journal of Electronic Commerce, Vol. 5, No. 3, pp.7-21.

Rezabakhsh, B., Bornemann, D., Hansen, U. and Schrader, U. (2006) 'Consumer power: a comparison of the old economy and the internet economy', Journal of Consumer Policy, Vol. 29, No. 1, pp.3-36.

Ryu, G. and Feick, L. (2007) 'A penny for your thoughts: referral reward programs and referral likelihood', Journal of Marketing, Vol. 71, No. 1, pp.84-94.

Sen, R., King, R.C. and Shaw, M.J. (2006) 'Buyers' choice of online search strategy and its managerial implications', Journal of Management Information Systems, Vol. 23, No. 1, pp.211-238.

Sheth, J.N., Sisodia, R.S. and Barbulescu, A. (2006) 'The image of marketing with consumers and business professionals', in J.N. Sheth and R.S. Sisodia (Eds.) Does Marketing Need Reform?, Armonk, NY: M.E. Sharpe, pp.26-36.

Sims, C. (2003) 'Implications of rational inattention', Journal of Monetary Economics, Vol. 50, No. 3, p.66.

Smith, J.W. (2006) 'Coming to concurrence: improving productivity by reengaging resistant consumers', in J.N. Sheth and R.S. Sisodia (Eds.) Does Marketing Need Reform?, Armonk, NY: M.E. Sharpe, pp.15-25.

Smith, M.D. (2002) 'The impact of shopbots on electronic markets', Journal of the Academy of Marketing Science, Vol. 30, No. 4, pp.446-454.

Smith, M.D. and Brynjolfsson, E. (2001) 'Consumer decision-making at an internet shopbot: brand still matters', Journal of Industrial Economics, Vol. 49, No. 4, pp.541-558.

Sotgiu, F. and Ancarani, F. (2005) 'The drivers of e-tailers' price levels', International Review of Retail, Distribution and Consumer Research, Vol. 15, No. 1, pp.75-89.

Stigler, G. (1961) 'The economics of information', Journal of Political Economy, Vol. 69, No. 3, pp.213-225.

Strader, T.J. and Shaw, M.J. (1999) 'Consumer cost differences for traditional and internet markets', Internet Research, Vol. 9, No. 2, pp.82-92.

Stylianou, A.C., Kumar, R.L. and Robbins, S.S. (2005) 'Pricing on the internet and in conventional retail channels: a study of over-the-counter pharmaceutical products', International Journal of Electronic Commerce, Vol. 10, No. 1, pp.135-148.

Suri, R., Long, M. and Monroe, K.B. (2003) 'The impact of the internet and consumer motivation on evaluation of prices', Journal of Business Research, Vol. 56, No. 5, pp.379-390.

Tang, F. and Xing, X. (2001) 'Will the growth of multi-channel retailing diminish the pricing efficiency of the web?', Journal of Retailing, Vol. 77, No. 3, pp.319-333.

Vilaseca, J., Torrent, J., Meseguer, T. and Rodriguez, I. (2007) 'An integrated model of adoption and development of e-commerce in companies', International Advances in Economic Research, Vol. 13, No. 2, pp.222-241.

Walter, Z., Gupta, A. and Su, B-C. (2006) 'The sources of on-line price dispersion across product types: an integrative view of on-line search costs and price premiums', International Journal of Electronic Commerce, Vol. 11, No. 1, pp.37-62.

Wright, L.T., Newman, A. and Dennis, C. (2006) 'Enhancing consumer empowerment', European Journal of Marketing, Vol. 40, Nos. 9-10, pp.925-935. 
Xing, X., Tang, F-F. and Yang, Z.L. (2004) 'Pricing dynamics in the online consumer electronics market', Journal of Product and Brand Management, Vol. 13, No. 6, pp.429-441.

Xing, X., Yang, Z. and Tang, F-F. (2006) 'A comparison of time-varying online price and price dispersion between multichannel and dotcom DVD retailers', Journal of Interactive Marketing, Vol. 20, No. 2, pp.3-20.

Zettelmeyer, F. (2000) 'Expanding to the internet: pricing and communications strategies when firms compete on multiple channels', Journal of Marketing Research, Vol. 37, No. 3, pp.292-308.

Zettelmeyer, F., Morton, F.S. and Silva-Risso, J. (2006) 'How the internet lowers prices: evidence from matched survey and automobile transaction data', Journal of Marketing Research, Vol. 43, No. 2, pp.168-181. 